\title{
OBSERVATIONS REGARDING THE BIOLOGY AND THE ECOLOGY OF THE SPECIES TURDUS PILARIS LINNAEUS 1758 IN THE WESTERN HALF OF ROMANIA
}

\author{
Aurelian Leonardo Ilie ${ }^{1, *}$, Mariana Marinescu ${ }^{2}$, Ilie Hoza ${ }^{3}$ \\ 1"Nicolae Jiga" Theoretical High School, Republicii Street, No. 36A, Tinca, Bihor, Romania \\ ${ }^{2}$ Teacher Training Department, University of Oradea, Universitatii Street, No. 1, Oradea, Bihor, Romania \\ 3’’Iustin Ilieșiu” Secondary School, Principala Street, No. 60, Anieș, Bistrița-Năsăud, Romania
}

Current Trends in

Natural Sciences

\begin{abstract}
The paper presents the results of the researches performed by the authors between 2000-2019 regarding the biology and the ecology of the species Turdus pilaris L. in the western half of Romania.The extension of the territory, breeding, clutch size, behaviour, number of generations, the phenology and food were studied. The height of nests above the ground varied till to 20 meters in a different trees. The nest is cup - shaped and the material of construction is extremely different : moss, roots, dry twigs, ground mixed with grass, herbs. It presents 2 -3 yearly generations, a complete clutch consists of $5-6$ eggs. The post - embrionic development lasts $12-16$ days. The phenology is different : in high hilly and the mountainous areas the species is sedentary, in low hilly and plain areas the species is partial migratory or passage or in many times winter visitor. The food is extremely different: insects, fruits, worms, spiders, molusca, little mammals.
\end{abstract}

Keywords: biology, ecology, Romania, Turdus pilaris

\section{INTRODUCTION}

Generally, Turdus pilaris L. is a common species in high hilly and mountainous areas (Figure 1).

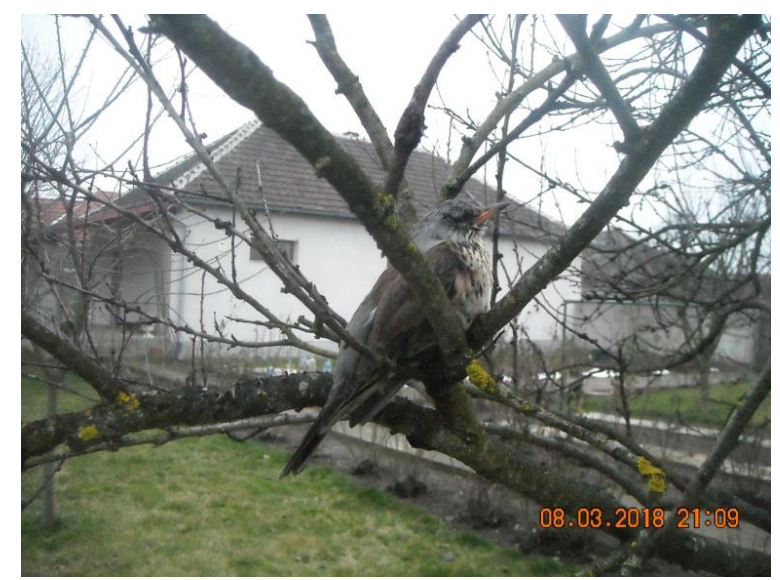

Figure 1 Turdus pilaris L. (photo Ilie A. L.) 


\begin{tabular}{|c|c|}
\hline . & 60 \\
\hline $\begin{array}{l}\text { Current Trends in Natural Sciences (on-line) } \\
\text { ISSN: 2284-953X } \\
\text { ISSN-L: } 2284-9521\end{array}$ & $\begin{array}{l}\text { Current Trends in Natural Sciences (CD-Rom) } \\
\text { ISSN: } 2284-9521 \\
\text { ISSN-L: 2284-9521 }\end{array}$ \\
\hline
\end{tabular}

Data regarding the biology and ecology of this species in different locations from Romania and Europe were published by different authors: Radu, 1984; Ciochia, 1992; Korodi - Gall, Beres, 1979; Molnar,1983 ; Munteanu,2012; Ilie,2008,2016,2017,2018; Bozo, 2019; Haland, 1984 ).

The extension of the territory to lower altitudes,increasingly drastic climate changes registered in the last years, all these determined the study of the biological and ecological aspects of this species in the western half of Romania.

\section{MATERIALS AND METHODS}

The reserches regarding the presence of the species, her biology and ecology began sporadically in 2000,then investigations were systematically realized beginning with the year 2009 till 2019 in different locations from the western half of Romania: Tinca,Oradea (Bihor county, north-western part of Romania), Anieș (Bistrița-Năsăud county, northern part of Romania), Craiova (Dolj county, south-western part of Romania).

\section{RESULTS AND DISCUSSIONS}

1.Breeding

With regard to breeding, we investigated the location of the nests, the material of construction, the clutch size and the development of nestlings. The height of nests above the ground varied from 1.20 meters (one nest identified, on the branches of a peach tree, Tinca) to 20 meters (in a pine tree, Anieș, April 10, 2015).The nest is installed generally on trees (deciduous or coniferous) being variable, between trunk and branches or on terminal part of the pine tree branches. The favourite places for the building of nests: orchards, edge of forests, parks, trees along roads. It manifests an obvious preference for human settlements,installing its nest very close to the buildings (exampletwo yards from Aniess school, 2018). The nest is cup - shaped and the material of construction is extremely different: outdoors there are dry twigs, roots, moss and inside is lined with ground mixed with grass, straw over which there is a lining made of fealthers, straw, herbs where the female puts eggs (Figure 2).

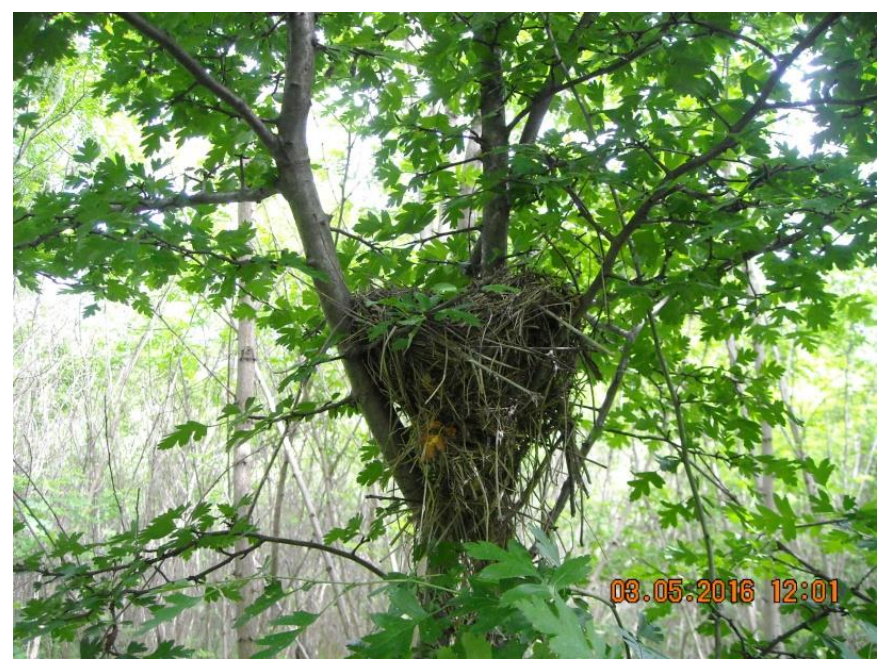

Figure 2 Nest of Turdus pilaris L. (Photo Ilie A.L.)

The nest can be used by a pair during 1-2 clutches, at the third clutch or even at the second clutch the pair will build a new nest.The diameters of the nests are variable:external diameter (142-160 $\mathrm{mm})$, internal diameter $(110-135 \mathrm{~mm})$, depth $(50-75 \mathrm{~mm})$. The yearly number of clutches is 
variable: 1 - 3 (2 - 3 in Anieș area, 460 meters altitude; 1 - in Tinca area, 115 meters average altitude). Generally, breeding in plain or hilly areas is sporadically (one clutch). The breeding is colonial, rarely solitary (at plain area). Thus, in Tinca area was identified only a nest on trees; in Anieș area there were identified 3 - 4 nests on a pine tree; in Craiova there were never identified breeding, being only winter visitor; in Oradea the breeding is possible,being identified an adult during the summer. The nest is build by both parents.

The number of eggs is variable: generally 5 - 6 (clutch I), 3 - 5 eggs (clutch II), 2-3 eggs (clutch III). The eggs are oval, smooth,with feeble lustre.The colour of the eggs is variable: green with fine spots and brown striped similar with the eggs of Turdus merula Linnaeus, 1758.

The size of the eggs: $28.5 \times 20.6 \mathrm{~mm}$. Clutches-the first clutch is laid in the period: April 10 - 20; the second clutch: June 13 - 25; the third clutch: first half of August. The hatching period generally lasts 11 - 14 days.

The post-embryonic development lasts 12 - 16 days, the nestlings are fed by both parents.

In the analyzed period we identified the harmful species: Accipiter nisus Linnaeus, 1758 and Accipiter gentilis Linnaeus, 1758 who hunt the adult birds; Pica pica Linnaeus, 1758 and Corvus frugilegus Linnaeus, 1758 eating eggs and nestlings.

Phenology : in high hilly and mountainous areas the species is sedentary, in low hilly and plain areas the species is partial-migratory, passage species or in many times winter visitor. In the last decade there was a tendency to extend the territory of the species to low hilly and plain areas.Thus, the species was identified at Oradea (one specimen, June 11, 2018) and in Tinca area the breeding of species was identified in 2015. Other locations of this species: Prunişor (Mehedinţi county, south-western part of Romania), August 17, 2017; Zerind (Timiș county, western part of Romania), August 11, 2017; Tămașda (Bihor county, north-western part of Romania), September 6, 2017. For winter or spring,this bird often shares in large groups, sometimes up to few hundred specimens. Example: 541 specimens, Tinca, March 20, 2018; 300 specimens, Tinca, March 4, 2018; 1100 specimens, Anieș, December 20, 2005, 165 specimens, Tulca (Bihor county), March 21, 2018.

The food is extremely different: worms, insects (mole crickets, coleopterans, butterflies, locusts, grasshoppers, flies), molusca (Helix genus), spiders and very rarely even little mammals (example one specimen of Sorex araneus Linnaeus, 1758, Anieș, June 12, 2017).

\section{CONCLUSIONS}

The researches performed during the period 2000 - 2019 on the species Turdus pilaris L. in the western half of Romania, emphasized the following aspects:

- in the last years there were observed an extension of species territory.

- it presents 2 - 3 yearly generations .- generally, a complete clutch consists of 5 - 6 eggs.

- the post - embrionic development lasts 12 - 16 days.

- the food is extremely different.

\section{REFERENCES}

Ciochia, V. (1992). Păsările clocitoare din România [Brooding birds from Romania], Ed.Științifică, București, 248 pp. (in Romanian )

Ilie, A.L. (2008). Monografie faunistică - Păsările din zona Tinca (județul Bihor, România), [The birds from Tinca area, Bihor county, Romania], Craiova: Ed.Sitech.110 pp. (in Romanian)

Ilie, A.L. (2016). Monografie faunistică. Organismele vertebrate din zona Tinca (județul Bihor, România), [Vertebrates from Tinca area, Bihor county, Romania], Craiova: Ed.Sitech. 267 pp. (in Romanian ) 


\section{Current Trends in Natural Sciences}

Vol. 10, Issue 19, pp. 453-456, 2021

https://doi.org/10.47068/ctns.2021.v10i19.060

Current Trends in Natural Sciences (on-line)

ISSN: 2284-953X

Current Trends in Natural Sciences (CD-Rom)

ISSN: 2284-9521

ISSN-L: 2284-9521

ISSN-L: 2284-9521

Ilie, A.L. (2017). Data about the fauna of vertebrates from the western half of Romania during 2016-2017. Educația omului de azi pentru ziua de mâine. No 14, 75-82.

Ilie, A.L. (2018). Faunistical data from Bihor county (Romania) during 2016 - September 2018. Educația omului de azi pentru lumea de mâine, No 15, 71-80.

Korodi-Gall, I., Beres, I. (1979). Contribuții la cunoaşterea răspândirii și biologiei reproducerii cocoșarului (Turdus pilaris L.) în România [Contributions to the knowledge of the biology and the reproduction of Turdus pilaris L].. Studii și comunicări. Societatea de Științe Biologice, Reghin, 165 - 170. (in Romanian).

Molnar, L. (1983). Date privind cuibăritul cocoșarului (Turdus pilaris L.) în mestecănişul de la Reci, Jud.Covasna [Data about the nesting of Turdus pilaris L. from Reci, Covasna county], Analele Banatului Științele Naturii, Timişoara, 159-162 ( in Romanian )

Munteanu, D. (2012). Conspectul sistematic al avifaunei clocitoare din România [The faunal view of the brooding avifauna in Romania], Cluj-Napoca: Ed. Alma Mater, 262 pp. (in Romanian)

Radu, D. (1984). Păsările în peisajele României [The birds in the landscapes of Romania], București: Ed.Sport-Turism, 404 pp. (in Romanian)

Bozo, L. ( 2019 ). Migration and wintering of Fieldfare (Turdus pilaris) in southeastern Hungary. Ornis Hungarica. Tom. 27, issue $2,87-99$.

Haland, A. ( 1984 ). Breeding ecology of alpine Fieldfare Turdus pilaris. Annales Zoologici Fennici. Tom. 21, No 3, $405-410$. 